\title{
FACTORS AFFECTING TOURIST REVISIT INTENTION IN BALI
}

\author{
Olivia Novrida Adrianty ${ }^{1}$, Chairy Chairy ${ }^{2 *}$ \\ ${ }^{1}$ School of Business, President University, Bekasi, Indonesia \\ Email: Nvrdolivia@gmail.com \\ ${ }^{2}$ School of Business, President University, Bekasi, Indonesia \\ Email: chairy@president.ac.id \\ *penulis korespondensi
}

Masuk : 04-02-2021, revisi: 23-03-2021, diterima untuk diterbitkan : 23-03-2021

\begin{abstract}
ABSTRAK
Tujuan penelitian ini adalah untuk menyelidiki faktor yang mempengaruhi niat mengunjungi kembali Bali sebagai tempat wisata. Penelitian sebelumnya menunjukan bahwa fasilitas wisata dan pengalaman estetika merupakan faktor utama yang mempengaruhi niat mengunjungi kembali. Dalam penelitian ini selain menyelidiki pengaruh kedua faktor di atas terhadap niat mengunjungi kembali, juga diselidiki peran pengalaman estetika sebagai mediator dalam hubungan antara fasilitas wisata dan niat mengunjungi kembali. Sampel penelitian ditarik dengan metode purposive sampling dan terdapat sebanyak 137 responden yang berpartisipasi dalam penelitian ini. Data diolah dengan menggunakan SEM-PLS. Hasil penelitian mengungkapkan bahwa fasilitas wisata dan pengalaman estetika memiliki efek positif terhadap niat mengunjungi kembali. Hasil penelitian juga memperlihatkan penglaman estetika sebagai mediator dalam hubungan antara fasilitas wisata dan niat mengunjungi kembali. Hasil studi ini diharapkan dapat menjadi masukan bagi pemasar tempat wisata di Bali dalam menarik lebih banyak wisatawan.
\end{abstract}

Kata kunci: Fasilitas wisata, Pengalaman Estetika, Niat mengunjungi kembali, Pariwisata, Bali

\section{ABSTRACT}

The purpose of this study is to investigate factors affecting revisit intention of Bali as tourist destination. Previous researches showed that tourist facility and aesthetic experience are important factors that predict tourist destination revisit intention. This research tried to show that these two variables are the predictors of revisit intention and aesthetic experience is the mediator in the relationship between tourist facility and revisit intention. The sample of this research is 137 respondents drawn using purposive sampling. The data were analysed using SEM-PLS. The research results showed that both tourist facility and aesthetics experience affected revisit intention significantly. This study also proved that aesthetics experience is the mediator in the relationship between tourist facility and revisit intention. This research is intended to give more guidelines for marketers to get more tourists to Bali.

Keywords: Tourist Facility, Aesthetic Experience, Revisit Intention, Tourism, Bali.

\section{INTRODUCTION}

\section{Research Background}

According to Feliciana (2016) there is a significant tourism's contribution to financial development. Tourism has become a major source of foreign currency revenue for some developing countries. Tourism is also a rapidly developing currency phenomenon and plays an important part of countries financial and technological growth. The tourism system promotes development of the basic framework, helps domestic industry grow, attracts foreign investment and promotes information exchanges. Beside has more than 17,000 islands, Indonesia has also more than 300 ethnic groups. That's why, Indonesia has thousands of tourist destinations (Chairy \& Syahrivar, 2019). According to the study of Tunjungsari et al (2019), other than MonasJakarta, Borobudur Temple-Yogyakarta, Toba Lake-Medan, and Raja Ampat-Papua, Bali island is one of the most visited tourist destination in Indonesia, especially the Kuta beach. Tourism Industry Indonesia (2016) reported that Bali is the most popular tourism in Indonesia and is expected to attract 20 million tourists in 2019. However, Bali failed to reach the target of 20 million foreign visitors by 2019, moreover, also in 2019 many cities in Indonesia are not 
included in the top ten cities in Asia Pacific destination. Indeed, for years Bali has proven to be the best tourist destination in the world encompassing all kind of traveller's holiday interest, whether in natural attractions, cultural richness and gastronomic adventures. Many factors affecting tourist decision to visit a destination, among others are motivation, attractiveness, image, facility, accessibility, perceived risk, e-word of mouth, and experience (Supriwanto \& Tunjungsari, 2020). This study explored the role of tourist facility and aesthetics experience in predicting revisit intention.

\section{Tourist Facility (TF)}

This study tries to explore Bali as tourist destination by investigating the role of tourist facility and aesthetic experience in influencing tourist revisit intention. This study is intended to discuss tourist facility since this aspect is one of the most important factors considered by tourist in choosing their vacation package. Tourist facility are all facility whose function is to meet the needs of tourists who stay for a while in the tourist destination they visit, where they can relax and enjoy and participate in activities available in the tourist destination. Basically, tourist facility are very important to support tourist needs Mill (2011). Bali, as one the most popular tourist destination, is still lack of adequate facility. For example at Goa Lawah beach, there are lack of tourist facility, such as toilet, thus many tourists complain of this situation (Mustofa, 2018). The same case found at Canggu beach and Berawa, street lights are still inadequate and traffic jams often occur during weekend (Nusa Bali, 2018). In Uluwatu Beach, there is a lot of plastic trash scattered, so there was a case, a well-known Hollywood actor who is the ambassador of the United Nations environmental environment from America, Adrian Grenier, voluntarily cleaned the trash (Kami, 2020).

\section{Aesthetic Experience (AE)}

The essence of an aesthetic experience is based on the vibrant cognitive and affective awareness of the viewer and on the personal significance of the viewer (Vessel et al, 2012). Over a long time, the concept of aesthetical experience has evolved and taken on a wide range of significances. An individual is somewhere in an aesthetic or in a passive situation. Examples of aesthetic experiences can be provided as examples of beaches, nature, museums, space travel or sightseeing in tourist destination. Aesthetic perception is symmetry, balance, harmony or quality. Consumption aesthetics are assessed somewhere as emotional capacity to activate visual attributes and service performances (Mathwick, 2001).

\section{Revisit Intention (RI)}

Revisit intention is the desires of tourists to participate in various types of tourism. It is one of the main focus of the existing literature on tourism (Lam \& Hsu, 2006). One of the main tasks is the desire and the need for a complete understanding of the buyer actions of tourists and predicting their potential buying intentions. The cost of attracting regular tourists is less than new customers. In contrast, tourists consistently spend more money (Lehto et al, 2004) and stay longer (Yan, Wang, \& Chen, 2013) compared with first time visitors. "Businesses can boost their profit by nearly $100 \%$, with just 5 percent more customers," (Reichheld \& Sasser, 1990) thus, a significant task and measure for managers should be to sustain competitiveness and create a memorable experience to attract tourists every year to visit their destination.

\section{METHODOLOGY}

This research adopted the quantitative descriptive design in which this design is generally used to observe an object and analyze the relationship between the independent variable, the mediating variable, and the dependent variable (Salkind, 2010). In this research, revisit intention 
is the dependent variable, tourist facility is the independent variable, and aesthetic experience is a mediator. This research attempted to analyse the direct and indirect effect of tourist facility on revisit intention, and the role of aesthetic experience as mediator.

This study used non-probability sampling, specifically the purposive sampling technique. The purposive sampling technique is a sampling technique where there is a criteria set by the researcher, and there is a filtering question to assure the sample meet the criteria (Sekaran \& Bougie, 2016). The respondents are 137 students of President University. The data were analysed using PLS-SEM.

\section{HYPOTHESIS DEVELOPMENT}

\section{Tourist Facility and Revisit intention}

Tourist facility are an important factor. According to Sammeng (2001), one of the key points to grow tourism is through facility. Tourist facility are among factors that attract tourist to visit a place, area or region. Therefore, tourism facility become an important factor that affect the revisit intention. Satisfaction with the tourist facility is another point that should be considered by marketers. Satisfaction implies a person's feeling of happiness or dissatisfaction by contrasting the perceived quality of the goods (services). When, on the contrary, performance is less than customer expectations, it is satisfied if the customer's expectations are met. Tourist satisfaction helps visitors to be faithful to destinations by returning and to recommend to others tourist destinations. Oliver (1999) notes that loyalty is a detailed pledge from the consumer to regularly return to or re-buy similar goods or services in the future. Based on above explanation, this study argues:

\section{H1: Tourist facility affects revisit intention}

\section{Tourist Facility and Aesthetic Experience}

Lee (2011) emphasizes the need to use aesthetic components like atmosphere, colour, decor, service and design that can add an aesthetic dimension to tourist destination. In another study it is shown the important of design components in tourist area such as colours, lighting, music and smell (Bekar \& Sürücü, 2017). The growth of tourism undoubtedly calls for tremendous facility, such as hotels, cafes, and shops. Faulty layout of these systems will harm the attractiveness of a tourist destination and have other negative effects on the natural and cultural environment along with most other anthropogenic activities (Wang, Xia, \& Chen, 2008) Therefore, if a tourist site has good facility it will lead to aesthetic experiences so that customers will feel satisfied and create of a revisit intention. Based on this argument, the second hypothesis is as follows:

\section{H2: Tourist facility affects aesthetic experience}

\section{Aesthetic Experience and Revisit Intention}

Aesthesia means symmetry, proportion, harmony or quality. The psychological activation of visual features and service output at a site is measured as the aesthetic in use (Mathwick et al.,2002). In an aesthetic experience, a person is in a passive way somewhere or in a situation. Aesthetic experiences of customers such as a visit to topic restaurants, gastronomy museums, space travel and sightseeing were explained by their linear positive relationship and re-visitation intent with nearly half of the changes in the re-visit intentions of customers. Customers aesthetic experiences have had a significant positive impact on customer reviews. Consequently, the more aesthetic experiences customers obtain, the more often they visit the same place (Bekar \& Sürücü, 2017). Based on this explanation, this study suggests:

\section{H3: Aesthetic Experience affects revisit intention}




\section{Tourist Facility, Aesthetic Experience, and Revisit intention}

Considering that previous research showed that there is a relationship between tourist facility and revisit intention (Sammeng, 2001), and also there is a relationship between tourist facility and aesthetic experience (Wang et al, 2008) On the other hand, Bekar and Sürücü (2017) showed a relationship between aesthetic experience and revisit intention. Based on this relationship among tourist facility, aesthetic experience and revisit intention, this study suggest that aesthetic experience has a role as mediator in the relationship between tourist facility and revisit intention. Therefore, the last hypothesis is as follows:

H4: Aesthetic experience mediates the relation between tourist facility and revisit intention

\section{RESULTS AND DISCUSSION \\ Respondent Profile}

Table 1 shows that the respondents of this research consists of 51.09 female and $48.90 \%$ male. The majority of the respondents are 18 - 25 years old $(81,75 \%)$, followed by $23-26$ years old $(18,24 \%)$. For monthly spending, Bali is mostly visited by students with an expenditure of 2 million to 5 million per month.

\begin{tabular}{lc}
\multicolumn{2}{c}{ Table 1. Respondent Profile } \\
\hline Demographic & Percentage \\
\hline Gender : & \\
Female & $51.09 \%$ \\
Male & $48.90 \%$ \\
\hline Age : & \\
$18-22$ & $81,75 \%$ \\
$23-26$ & $18,24 \%$ \\
\hline Monthly spending : & $36,49 \%$ \\
$<2.000 .000$ & $46,71 \%$ \\
$2.000 .000-5.000 .000$ & $16,78 \%$ \\
$>5.000 .000$ & \\
\hline
\end{tabular}

Table 2. Descriptive Analysis

\begin{tabular}{llllll}
\hline & Mean & SD & TF & AE & RI \\
\hline Tourist Facility (TF) & 4,25 & 0,78 & 1,000 & & \\
Aesthetic Experience (AE) & 4,30 & 0,79 & 0,640 & 1,000 & \\
Revisit Intention (RI) & 4,30 & 0,83 & 0,607 & 0,66 & 1,000 \\
\hline
\end{tabular}

Table 2 shows the variable correlation, means and standard deviation. The tourist facility has mean and standard deviation, $\mathrm{M}=4,25$ and $\mathrm{SD}=0,78$, while aesthetic experience has $\mathrm{M}=4,30$ and $\mathrm{SD}=0,79$. Revisit Intention has $\mathrm{M}=4,30$ and $\mathrm{SD}=0,83$. All correlations are statistically meaningful.

Table 3. Loading factors of the Model

\begin{tabular}{lc}
\hline Item & Loading \\
\hline Tourist Facility & \\
Bali has a suitable accommodation & 0,786 \\
Bali has a good nature environment & 0,779 \\
Bali has a rich cultural & 0,802 \\
\hline Aesthetic Experience & \\
\hline
\end{tabular}




\begin{tabular}{ll} 
I felt a real sense of Happiness in Bali & 0,783 \\
Just being in Bali was very pleasant & 0,651 \\
The Game arena in Bali was challenging (surfing, diving, snorkling) & 0,756 \\
The beach was very attractive & 0,739 \\
The View in Bali really gives a different sensation and united with $\quad$ the nature & 0,782 \\
The beach in Bali a provide pleasure to my senses & 0,822 \\
\hline Revisit Intention & 0,804 \\
\hline I really like the tourist Facility in Bali & 0,817 \\
I will visit Bali again & 0,768
\end{tabular}

Table 3 shows the result of loading factors of the research model. Tourist facility has 3 items, the higher one is 0,802 and the small one is 0,779 . Aesthetic experience has 6 items, the higher one is 0,882 and small one is 0,651 . Revisit intention has 3 items, the higher one is 0,817 and small one is 0,768 . To comply with the test of validity, Sekaran \& Bougie (2016) stated the minimum of 0.600 Cronbach Alpha, and the AVE parameters should exceed 0.500. The result showed values that meet the validity test.

Table 4. Reliability and Convergent Validity

\begin{tabular}{ll|l|lll}
\hline & $\begin{array}{l}\text { Cronbach's } \\
\text { Alpha }\end{array}$ & rho_A & $\begin{array}{l}\text { Composite } \\
\text { Reliability }\end{array}$ & $\begin{array}{l}\text { Average } \\
\text { Extracted (AVE) }\end{array}$ & Variance \\
\hline AE & 0,850 & 0,856 & 0,889 & 0,574 \\
RI & 0,712 & 0,712 & 0,839 & 0,635 \\
TF & 0,697 & 0,698 & 0,832 & 0,622 & \\
\hline
\end{tabular}

Table 4 shows the value of the Cronbach's alpha, rho_A, composite reliability, and AVE. Aesthetic experience has $C A=0,850$, rho_ $A=0,856, C R=0,889$ and $A V E=0,574$. While revisit intention has $\mathrm{CA}=0,712$, rho_ $A=0,712, \mathrm{CR}=0,839$ and $\mathrm{AVE}=0,635$. Tourist facility has $\mathrm{CA}=0,697$, rho_A $=0,698, \mathrm{CR}=0,832$, and $\mathrm{AVE}=0,622$.

Table 5. Discriminant Validity

\begin{tabular}{llll}
\hline & AE & RI & TF \\
\hline AE & 0,757 & & \\
RI & 0,660 & 0,797 & \\
TF & 0,640 & 0,607 & 0,789 \\
\hline
\end{tabular}

Table 5 shows that the variables in this study is qualified fulfilling the criteria. The square root should be greater than the association of each structure in evaluating discriminating validity. It is suggested that each factor in the same column should have a higher AVE square root than its correlation. The diagonal elements shown in Table 5 are larger than between each factor. The researcher therefore confirmed that discrimination validity was fulfilled.

Table 6 shows the result of PLS-SEM analysis. The effect of TF on RI is significant $(t=4,848$, $\mathrm{p}<0.05)$, thus $\mathrm{H} 1$ is supported. The result also suggests that $\mathrm{TF}$ affects $\mathrm{AE}(\mathrm{t}=8,828, \mathrm{p}<0.05)$, $\mathrm{H} 2$ is supported. Further, there is a direct impact of AE on RI $(t=3,078, p<0,05)$, thus H3 is supported. H4 is also supported $((\mathrm{t}=3,004, \mathrm{p}<0,05)$, AE mediates the relationship between TF and RI. 
Table 6. PLS-SEM Result

\begin{tabular}{lrcc}
\hline \multicolumn{1}{c}{ Hypothesis } & t-value & p-value & Supported \\
\hline Direct Effect & & & \\
H1: TF - RI & 4,848 & 0.000 & Yes \\
H2: TF - AE & 8,828 & 0.000 & Yes \\
H3: AE - RI & 3,078 & 0.000 & Yes \\
Indirect Effect & & & \\
& & & \\
H4 TF -AE -RI & 3,004 & 0.000 & Yes \\
\hline
\end{tabular}

\section{Discussion}

This research explores the relationship between tourist facility and the revisit intention, as well as the relationship between aesthetics experience and revisit intention. This study also explores the role of aesthetics experience as a mediator in the relationship between tourist facility and the revisit intention. The result shows that all hypotheses are supported. The first hypothesis that stated there is a significant effect of tourist facility on revisit intention is supported by the data. This result supports the previous research result by Sammeng (2001). The second hypothesis that predict there is a direct relationship between tourist facility and aesthetics experience, also supported by the data. This result supports the works of Lee (2011), Wang et al (2008), and Bekar and Sürücü (2017). The third hypothesis that assumes there is an effect of aesthetics experience on revisit intention is also supported by the data. The same supported result is obtained for $\mathrm{H} 4$. There is a mediating effect of aesthetics experience in the relationship between tourist facility and revisit intention. This result is in line with the works of Mathwick et al. (2002) and Bekar and Sürücü (2017).

\section{CONCLUSION AND RECOMMENDATION}

There are three hypotheses in this study. The first is to investigate the effect of tourist facility on the revisit intention. The second is to check whether there is an influence of aesthetics experience on revisit intention. The third hypothesis is about the role of aesthetics experience as a mediator in the relationship between tourist facility and the revisit intention. The result of this study supports all hypotheses mentioned above. It means that to support the tourism in Bali, it is important to pay attention on tourist facility and aesthetics experience. By enhancing these two factors, the revisit intention of tourist to Bali could be maintained and developed. Further, it will also create employment for local citizen.

\section{REFERENCES}

Bekar, A., \& Sürücü, Ç. (2017). The effects of aesthetic value in food and beverage businesses on the aesthetic experiences and revisit intentions of customers. Journal of Academic Social Science Studies, (54), 373-388.

Chairy, \& Syahrivar, J. (2019). Bika Ambon of Indonesia: history, culture, and its contribution to tourism sector. J. Ethn. Food 6, 2. https://doi.org/10.1186/s42779-019-0006-6

Feliciana, J. (2016). An analysis of city image tourism business toward foreign tourist decision. Unpublished Thesis, President University. 
Kami, I. M. (2020, March 09). Bersihkan Sampah di Bali, Aktor Hollywood Adrian Grenier Beri Pesan Penting. Retrieved from Detikhot: https://hot.detik.com/celeb/d4931368/bersihkan-sampah-di-bali-aktorhollywood-adrian-grenier-beri-pesan-p

Lam, T., \& Hsu, C. H. (2006). Predicting behavioral intention of choosing a travel destination. Tourism Management, 27 (4), 589-599. ttps://doi.org/10.1016/j.tourman.2005.02.003.

Lehto XY, Cai LA, O'Leary JT, Huan T-C. (2004). Tourist shopping preferences and expenditure behaviors: The case of the Taiwanese outbound market. Journal of Vacation Marketing. 10(4):320-332. doi:10.1177/135676670401000404

Mathwick, C., Malhotra, N. \& Rigdon, E. (2001). Experiential value: conceptualization, measurement and application in the catalog and Internet shopping environment, Journal of Retailing, 77 (1), 39-56. https://doi.org/10.1016/S0022-4359(00)00045-2.

Mathwick, C., Malhotra, N. \& Rigdon, E. (2002). The effect of dynamic retail experiences on experiential perceptions of value: An Internet and catalog comparison. Journal of Retailing, 78(1):51-60. https://doi.org/10.1016/S0022-4359(01)00066-5.

Mill, R. C. (2011). Tourism in the International Business. Open Textbooks for Hongkong, The Open University of Hong Kong.

Mustofa, A. (2018, November 27). Belum Memadai, Fasilitas Objek Wisata Goa Lawah Dikeluhkan Wisatawan. Retrieved from Radar Bali: https://radarbali.jawapos.com/read/2018/11/27/105626/belum-memadai-fasilitas-objekwisata-goa-lawah-dikeluhkan-wisatawan

Nusa Bali. (2018, Nopember 10). Fasilitas Penunjang Pariwisata di Canggu Dinilai Minim. Retrieved from Nusa Bali: https://www.nusabali.com/index.php/berita/41366/fasilitaspenunjang-pariwisata-di-canggu-dinilai-minim

Oliver, R. L.(1997). Satisfaction a behavioral perspective on the consumer. Singapore: McGraw Hill.

Reichheld , F. F., \& Sasser, W. E. (1990). Zero defections: quality comes to services. Harvard Business Review, 68 (5), 105-111.

Salkind, N. J. (2010). Encyclopedia of research design. Thousand Oaks, Calif: SAGE Publications.

Sammeng, A.M. (2001). Cakrawala Pariwisata. Jakarta: Balai Pustaka.

Sekaran, U., \& Bougie, R. J. (2016). Research Method for Business. $7^{\text {th }}$ edition. New York: Wiley.

Supriwanto \& Tunjungsari, H. K. (2020) Mediasi Tourist's Engagement dalam Pengaruh Interactive e-Referral pada Intention to Visit dan e-Referral Sharing Behavior Festival Cap Go Meh Singkawang. Jurnal Muara Ilmu Ekonomi dan Bisnis, Vol. 4 (2), 261-273. DOI: $10.24912 / \mathrm{jmieb} . v 4 \mathrm{i} 2.8031$

Tourism Industry Indonesia. (2016, December 16). Retrieved from Indonesia Investment: https://www.indonesia-investments.com/business/industriessectors/tourism/item6051

Tunjungsari, H. K., Selamat, F., \& Chairy, C. (2019). Pengukuran Destination Awareness Wisatawan Domestik pada Candi Muaro Jambi. Jurnal Komunikasi, 11(2), 233-247. DOI: $\underline{10.24912 / \mathrm{jk} . v 11 \mathrm{i} 2.5796}$

Vessel EA, Starr GG \& Rubin N (2012) The brain on art: intense aesthetic experience activates the default mode network. Front. Hum. Neurosci. 6:66. doi: 10.3389/fnhum.2012.00066 
Wang, Y., Xia, Z. and Chen, Wei (2008). Aesthetic values in sustainable tourism development: A case study in Zhangjiajie National Park of Wuling Yuan, China. Journal of China Tourism Research, 4 (2), 205-218.

Yan, X., Wang, J. \& Chau, M. (2013). Customer revisit intention to restaurants: Evidence from online reviews. Inf Syst Front 17, 645-657 (2015). https://doi.org/10.1007/s10796-0139446-5 